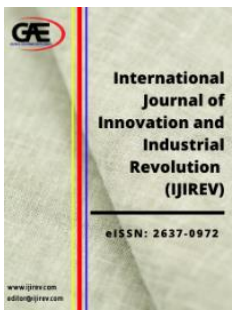

\author{
INTERNATIONAL JOURNAL OF \\ INNOVATION AND \\ INDUSTRIAL REVOLUTION \\ (IJIREV) \\ www.ijirev.com
}

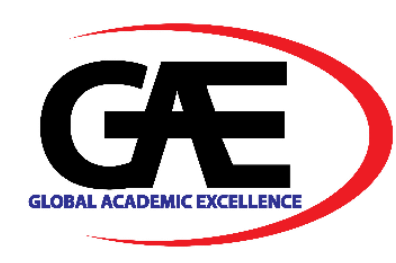

\title{
THE EFFECTS OF MARKET ORIENTATION, PRODUCT INNOVATION AND MARKETING ETHICS ON FIRM PERFORMANCE: A THEORETICAL FRAMEWORK
}

\author{
Moad Hamod M Saleh ${ }^{1 *}$, Adi Anuar Azmin², Ummi Naiemah Saraih ${ }^{3}$ \\ 1 Faculty of Applied and Human Sciences, Universiti Malaysia Perlis, Malaysia \\ Email: moad.hamod2000@hotmail.com \\ 2 Faculty of Applied and Human Sciences, Universiti Malaysia Perlis, Malaysia \\ Email: adianuar@unimap.edu.my \\ 3 Faculty of Applied and Human Sciences, Universiti Malaysia Perlis, Malaysia \\ Email: ummi@unimap.edu.my \\ Corresponding Author
}

\section{Article Info:}

\section{Article history:}

Received date:01.05.2021

Revised date: 03.06.2021

Accepted date: 22.06.2021

Published date: 30.06 .2021

\section{To cite this document:}

Saleh, M. H. M., Azmin, A. A., \& Saraih, U. N. (2021). The Effects of Market Orientation, Product Innovation and Marketing Ethics on Firm Performance: A Theoretical Framework. International Journal of Innovation and Industrial Revolution, 3 (7), 31-47.

DOI: $10.35631 /$ IJIREV.37004

This work is licensed under $\mathrm{CC}$ BY 4.0

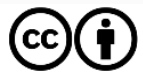

\begin{abstract}
:
In the contemporary business environment, market orientation has become a widely discussed topic in the business community and academics. Since the market environment has become more competitive, developing and improving one's internal resources is now an absolute necessity. Despite the influence these topics have on the performance of microenterprises, a significant number of market orientation studies haven't empirically connected them. According to this perspective, this study established a theoretical link between market orientation and SME performance via a literature review. Additionally, a new framework for experimental evidence was developed. This study makes significant contributions to the understanding of the relationship between market orientation and SME performance but also sheds light on the critical role of product innovation as a mediator. Furthermore, the conceptual model explains the impact of marketing ethics as a moderator on small- and mediumsized enterprise (SMEs) performance.
\end{abstract}

Keywords:

Market Orientation, Costumer Orientation, Competitor Orientation, Internal Functional Coordination, Product Innovation, Marketing Ethics, Firm Performance 


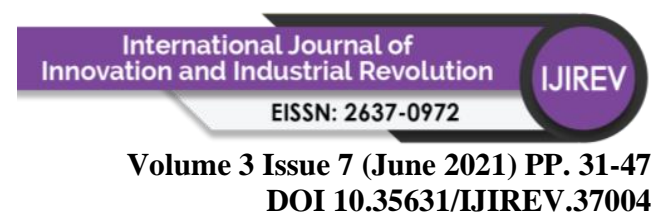

\section{Introduction}

Globalization, global rivalry, and changes in customer requirements and wishes have all increased histrionically over the last decade (Ali, et al.,2020). Furthermore, the majority of industrial sectors in developing-country economies are undergoing structural and rapid changes, resulting in economic opportunities for FDI, unbalanced development, and increased uncertainty as a result of environmental changes (Calza, E., \& Goedhuys, M. (2017); Chironga, et al., 2011). Surprisingly, these changes have created both critical challenges and opportunities for businesses to capitalize on their abilities or proficiency for development (De Vos, et al., 2015). These changes have also had an effect on the decision-making processes and managerial assumptions of a number of entrepreneurial firms, including those made to capitalize on opportunities and methods for creating and delivering customer value $(\mathrm{Wu}, \&$ Pagell, 2011; Hughes, \& Morgan, 2007). To improve their efficiency and competitiveness on this point, numerous businesses are empowered to alter their classical business processes and to design and implement the most effective strategies to improve goods and services in order to make sure customer satisfaction at a reasonable cost (Goksoy, et al.,2012; Teixeira, et al., 2015). As a consequence, Businesses must embrace and apply market orientation (MO) and new operational management activities that have been demonstrated to be efficient in longterm (Jiang, et al., 2020; Ali et al., 2018; Hakala, 2011; Li, et al., 2008). In line with this, many authors, emphasized the importance of market orientation and product innovation in gaining a competitive advantage and improving firm performance (Al-Henzab, et al., 2018; Al-Dhaafri, et al., 2013; Aziz \& Yassin, 2010; Talib, et al., 2010 Li et al., 2008). In addition, prior research has identified marketing ethics (ME) as a source of long-term competitive advantage and a significant driver of the best performance (Moravcikova, et al., 2017; Singh, et al., 2019; Wang, 2019; Hopkins, et al., 2021).

Notwithstanding, the vast majority of existing research on market orientation, product innovation, and firm performance is centered at sizable organizations, especially in developed countries (Mpandare, \& Li, 2020; Ali, 2020; Salaheldin, 2009; Mahmoud, 2011; Wales, et al.,2011; Raju, et al., 2011). Contrastingly, there are smaller number researches obtainable on market orientation, product innovation, and marketing ethics in SMEs (Chiarelli, 2021; Jabeen \& Mahmood, 2015; Filser, et al., 2014; Islam, et al., 2011; Raju et al., 2011; Chao \& Spillane, 2010). On the basis of the preceding proposition, it is reasonable to assume that past studies have not only paid scant attention to market orientation and product innovation in SMEs, even so there are various conceptual and empirical possibilities to conceptually and empirically broaden the study about MO, PI, and firm performance. Subsequently, the particular goal of paper is to provide the scientific society with a theoretical model that will connect MO, PI, ME, and SMEs' performances, in addition to contributing to the existing knowledge and facilitating interactions between advanced countries and other emerging and developing countries like Saudi Arabia.

\section{Literature Review}

\section{Market Orientation (MO)}

Market orientation is a business philosophy that places a premium on identifying consumer needs and desires and meeting them through products and services. (Udriyah, et al., 2019). The most recent researchers are adamant that firms should pursue market orientation because it enables firms to achieve long-term competitive advantage (Fakhreddin, et al., 2021; Hernández-Linares, et al., 2021; Alhakimi, \& Mahmoud, 2020; Ho, et al., 2018). Furthermore, 


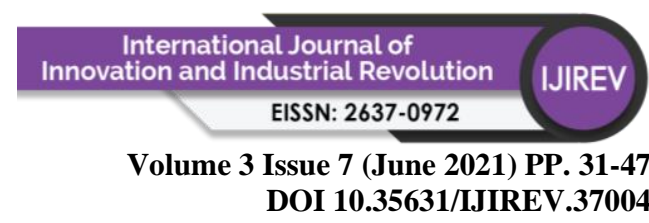

Market orientation is viewed as an organization's capacity, unique and valuable resources that cannot be readily replicated, emphasizing the importance of putting the customer's needs first in operations and strategy (Mostafiz, et al., 2021; Polat \& Mutlu, 2012). At its most fundamental level, market orientation refers to a company's capacity to investigate and identify existing and potential consumer wants, and then work to meet those wants more effectively (Slater, \& Narver, 1995; Day, 1994; Kohli, \& Jaworski, 1990). In simple words, market orientation agrees that it is necessary to establish a more personal relationship with the customer (Slater \& Narver, 1998). In this framework, market orientation refers to an organization's ability to act quickly by introducing new products and services in response to changes in market demand (Ali, et al., 2017; Adis \& Jubilee, 2010). As a result, it stands to reason that market orientation activities will have an impact on a firm's innovativeness (Ali, et al., 2017).

Notably, Slater \& Narver, (1995) and Kohli, A. K., \& Jaworski, B. J. (1990) provided the first conceptualizations of market orientation that were recognized as the primary determinant of firm performance. Other several studies, however, have been handled following the work of Narver, \& Slater, (1990) and Kohli, \& Jaworski, (1990), which established a link between business performance and market orientation. Market orientation is defined by Kohli, \& Jaworski, (1990) as "organization-wide generation of market intelligence pertaining to current and future customer needs, dissemination of the intelligence across departments, and organization-wide responsiveness to it". Market orientation, on the other hand, was viewed as a type of organizational culture by Narver, \& Slater, (1990). They define market orientation as "the organizational culture that most effectively and efficiently creates the necessary behaviours for the creation of superior value for buyers and, as a result, continues superior performance for the business". In this regard, Kohli and Jaworski (1990) define market orientation as a three-part process that includes "intelligence generation, intelligence dissemination, and enterprise-wide responsiveness". According to additional researchers, for example, Narver, \& Slater, (1990), market orientation has three dimensions: "competitor orientation, customer orientation, and internal functional coordination". However, both market orientation approaches share a common objective, which means that customers remain the primary focus of market orientation thinking and explanations of firm behavior (Acosta, et al., 2018; Shehu \& Mahmood, 2014; Vieira, 2010). Numerous market-oriented studies have concluded that market-oriented culture is a significant predictor of improved business performance because it places a premium on customer needs, whereas the market-oriented business strives to improve customer satisfaction, thereby increasing firm performance (Ali, et al., 2017; Olabode, et al., 2018; Morgan, et al., 2019). As a result, marketing literature has regarded MO as an important component of organizational culture (Morgan, et al., 2019; Raju et al., 2011). In fact, the majority of market orientation studies have evaluated the market orientation construct using these three dimensions (e.g., Olabode, et al., 2018; Ali, et al., 2017; Wilson, et al., 2014; Julian, et al., 2014; Aziz \& Omar, 2013; Augusto \& Coelho, 2009; AppiahAdu \& Ranchhod, 1998). Numerous researchers have discovered a a relationship among organization performance and market orientation in large corporations, especially in developed countries (Alhakimi, \& Mahmoud, 2020; Ali, et al., 2017; Raju et al., 2011; Mahmoud, 2011). As a result, study on the effects of market orientation on SMEs is scarce (Ali, et al., 2017; Islam, et al., 2011). Additionally, Herath, \& Mahmood, (2013) argue for the addition of a mediator in the correlation between strategic orientation and firm performance. Furthermore, research has shown that MO improves organizational performance (Lekmat, et al., 2018; Sisay, et al., 2017; Joensuu-Salo, et al., 2018; Suliyanto, \& Rahab, 2012; Chen, et al., 2015). 


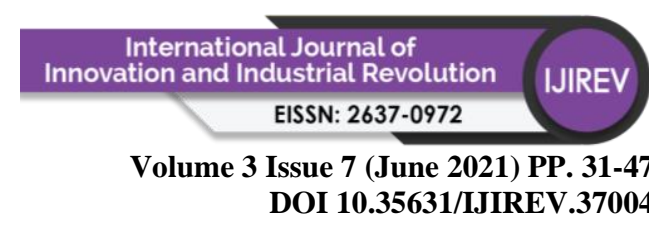

Similarly, if a market-oriented company distinguishes and struggles to meet customer needs, desires, and preferences better than competitors, the level of firm performance increases. (Prifti, \& Alimehmeti, 2017). Likewise, to address changing customer tastes and expectations, several businesses have embraced the market orientation philosophy, which is widely regarded as one of the most considerable improvements in the literature of marketing (Suliyanto, S., \& Rahab, R. (2012)).As a result, each organisation follows market orientation as a strategy for developing marketing capabilities in order to meet and exceed customer expectations while outperforming competitors (Ali et al.,2017; Li, et al., 2009; Chin, et al., 2013). Furthermore, numerous previous researches have demonstrated a connection among market orientation and product innovation (Zelbst, et al., 2010; Lam, et al., 2012). According to these findings, MohrJackson (1998) and Day, G. S. (1994) established a connect amidst market orientation and product innovation because both are responsive to the needs of the customers, involve customer participation, and ultimately aim to achieve customer satisfaction. Indeed, product innovation provides businesses with a set of tools to help them become more market-oriented (Litton, 2001). Additionally, Day, G. S. (1994) asserts that "a market-oriented firm enhances the process of market and customer sensing". Consequently, associating capacities is a critical component of a firm's construction; consequently, product innovation implementation aids in capability enhancement, and at its core is the concept of an organization as an interconnected collection of processes rather than an interacting set of functional units. As a result, marketing and product innovation are mutually beneficial (Herman, et al., 2018; Wang, et al., 2012).

\section{Customer Orientation}

Customer orientation is one of the dimensions of MO. It is described as an organization's understanding of customer demands and possession of capacity to continually create superior products and services that will add value to the customers (Neneh, 2018; Narver \& Slater, 1990). Kohli and Jawoski (1990) in this view pointed out that customer orientation is a key factor of MO. Importantly, Feng, et al., (2019) and Jaakkola, et al., (2009) defined customer orientation as a process which a firm follows to meet customer's need and satisfaction. With this in mind, the company must provide every necessary information on the products and the level to which the product can satisfy customer needs and needs. Customer orientation requires the organization to collect customer information and understand the whole value chain (Arief et al., 2013). The customer is the center on which all the marketing activities of any organization are focused. The organization's market competitiveness depends on the level of satisfaction it gives to customers (O'Dwyer, \& Gilmore, 2018). Organizations seeking to be on the lead in terms of competition are those which can actualize and translate the customer's needs into products or services that match his or her desires, achieving greater and better satisfaction than other competitors. Accordingly, customer orientation, as Narver \& Slater (1990) indicate, reflects the organization's ability to identify customers' needs and determine the factors affecting their purchase decisions.

Racela, \& Thoumrungroje (2019), add that customer orientation reflects the organization's understanding of customer goals to create superior value for them. This requires sellers to fully understand customers' value chain, not only as it currently exists but as also as it will be in future. Hence, the organization is required to do following: Firstly, emphasizing, customer's needs and desires analysis. Lastly, responding to the information received on customer's needs and preferences. In the same context, Smirnova, et al., (2018) explains that customer orientation strategy is the main reason that enabled the Japanese to achieve miracles, pointing out that there are a number of factors that may hinder the success of this strategy, including: 


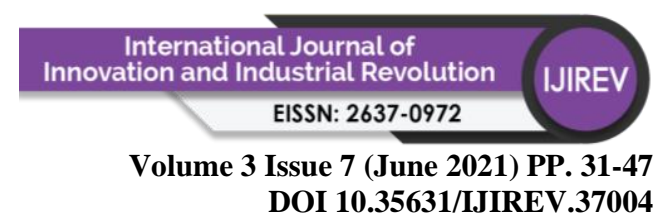

Firstly, decision-makers are distanced from clients. Secondly, frozen policies in the organization. Lastly, failure to give low administrative level employees the powers to solve problems.

Meanwhile, Neneh, (2018) and Saidani (2008) explain that interest in satisfying consumer needs is very important and has become a priority for organizations, as technological advances and competition over customer satisfaction have increased, signalling a good indicator of the future benefits of organizations and the achievement of their strategic goals. Not only this, a Japanese businessman sees that the goal is to go beyond the stage of satisfying consumers to that of making them happy which is deeper and higher than just satisfying the consumer and meeting his expectations (Bowden, 2009). If the customer is pleased with the product or service provided, he /she will be the best advertiser for the company and its products, while a dissatisfied consumer will have a negative impact on the company's reputation Customer orientation is one of the dimensions of MO.

For instance, Sa, M et al., (2020) and Christensen and Bower (1996), assert that the failure of many large organizations can be attributed to their attitude of listening 'excessively' to their customers since the customers often place 'too strict limits' on the firm strategies that make it difficult for a good milestone to be achieved. Justifying this position is the fact that the customers on frequent occasions lack the knowledge of how their needs surface while they cannot also ascertain how technology may be used to influence or satisfy such needs. Thus, it is very important for practitioners to conceptualize and develop new services or products which have resemblance with existing ones based on the feedback of customers with the objective of satisfying their clients (Zhang, H., Kang, F., \& Hu, S. Q. (2020). The position of this study, however, is that the school of thought that believes that customer orientation may negatively influence firm performance based their view on parochial comprehension of the meaning of customer orientation (Appiah-Adu, \& Singh, 1998). In fact, as argued earlier, previous studies have established that being customer-oriented transcends attentiveness; but the ability to understand how such needs arise and how they will be fulfilled is very important for the firm (Augusto \& Coelho, 2009; Slater \& Narver, 1998). As a result, the following effects can be predicted:

H1: There is significant effect of consumer orientation on firm performance.

H4: There is a significant and positive relationship between consumer orientation and product innovation of SMEs in Saudi Arabia.

\section{Competitors Orientation}

Narver and Slater (1990) asserted that competitor orientation is one of the dimensions of MO that helps firms in identifying and analyzing current and potential competitors taking into consideration a complete set technology required to satisfying current and potential customer's needs. In this circumstance, surveying the competitors' position can assist a firm to identify the rising substitutes, the degree with which such substitutes can be metusing the technologies, and the moments through which technology shifts (O'Dwyer, \& Gilmore, 2019; Zahra, Nash \& Bickford, 1995). In fact, the position of Zahra et al., (1995) is that this information is instrumental to research and development planning since such can be used to determine when to enter the market and how to select the appropriate strategy that will help in improving performance. This fact has also been corroborated by Augusto \& Coelho (2009) that, without competitor knowledge, managers may work in vain as they may not be able to identify alternative courses of action which are best used to protect and enhance their present position. 


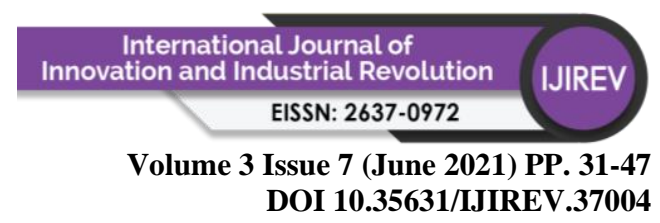

Further and as noted by Gaur et al., (2011), organizations with higher degree of competitor orientation may have an enhanced understanding of those important elements in the moves of competitors, purchasers' value chain and how those moves change with time (Crick, et al.,2020; Day \& Wensley, 1988). Such understanding can be instrumental for the firm to build and deliver superior value to a customer with subsequent positive impact on the firm performance as following competitors' moves closely may also facilitate innovation by being wary of what type innovative strategy that is being adopted by the competitors (Gaur et al., 2011; Johnson, et al., 2009). Despite the tremendous merits of competitor orientation, some other studies have argued that excessive concentration on competitors may weaken the ability of an organization to differentiate itself and, as such, may deflect its ability to properly monitor the changes in customer needs and market segments, thereby reducing the conception and development of innovative strategies (Day \& Wensley, 1988).

This will indicate that excessive focus on competitor will inhibit breakthrough in products development thereby leading to mediocrity (Augusto \& Coelho, 2009). Other authors have also seemed to agree with this position, such as Bennett and Cooper (1981), and Hayes and Abernathy (1980) cited in Augusto and Coelho (2009) stating that intense concentration on competitors' activities may lead to imitation instead of innovation while risk, launching, and development costs are reduced. This perhaps made Lukas and Ferrell, (2000) to observe that a penchant for monitoring competitor position may negatively affect the development of product innovation. Juxtaposing the arguments from the two schools of thoughts above, this study aligns with the position that competitor orientation is capable of improving the performance of a firm positively. This fact has been corroborated by recent studies that assert that the ability of a firm to identify and understand the long-term capabilities for both present and future competitors as well as the short-term weaknesses will go a long way to assist the firm in improving its performance. According to Grinstein, (2008), and Singh, (2009), when a mechanism is put in place for every employee in marketing-oriented firms to share information about competitors, a high level of competitive and sustainable advantage for the firm will be achieved. It, therefore, connotes that customer orientation is as imperative as competitor orientation. As a result, the following effects can be predicted:

$\mathrm{H} 2$ : There is significant effect of competitor orientation on firm performance.

H5: There is a significant and positive relationship between competitor orientation and product innovation of SMEs in Saudi Arabia.

\section{Internal Functional Coordination}

Internal functional coordination helps different functional units to jettison their primary functional interests and collaborate with one another with the purpose of achieving the global objectives of the organization (Mubarak, 2019; Augusto \& Coelho, 2009). Similarly, Julian et al., (2014) asserted that internal functional coordination has also been recognized as a situation where each department is regarded to be important irrespective of whether such a department belongs to marketing unit or not as each department has significant role in satisfying the customers (Waruiru, et al., 2018; Grinstein, 2008; Im \& Workman, 2004; Singh, 2009). Importantly, the inter-functional coordination process ensures smooth collaboration, cohesiveness, communication, trust, and functional commitment among departments (Auh \& Menguc, 2005), so this can bring about superior result in product or service innovation (Gatignon \& Xuereb, 1997). Since this is a form of integration, it does foster cross breeding of ideas and facilitates internal dispersion of such ideas (Huang, Lai, Hu \& Weng, 2014). Hence, such coordination is required to communicate information that is gathered from competitors 


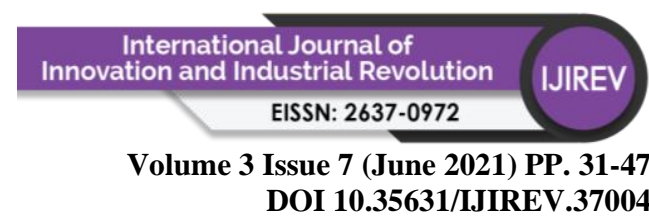

and customers in order to coordinate interdepartmental efforts with the purpose of providing superior value to the customer (Huang et al., 2014).

Furthermore, offering a new product or technology requires inter-functional collaboration with the purpose of solving market and technical issues that will lead to achieving high speed and performance (Tajeddini, et al., 2017; Zahra et al., 1995). Importantly, previous studies have equally argued that organizations with enhanced interfaces between research and development and marketing departments are able to achieve their technological capacity efficiently than their competitors through identification of product innovation. As equally noted by Gaur et al., (2011) when there is a high level of coordination among departments, facilitation and sharing of important information may be achieved as this will help the organization to quickly and efficiently respond to the stimuli in an external environment (Tyler \& Gnyawali, 2002). In fact, a single department has very limited strength while integration of different departments can help to accomplish higher order achievements which might elude or not within reabn or capacity of a single unit (Ruekert \& Walker, 1987). In fact, many studies have supported the connection between innovation and coordination (Augusto \& Coelho, 2009; Damanpour, 1991).

However, the benefits of internal functional coordination in improving the performance of an organization have been challenged as other studies have argued against it and do not give significant support for a positive relationship. This has equally been supported by others who asserted that internal functional coordination has no correlation with product innovation and performance (Hübnerová, et al., 2020; Lukas \& Ferrell, 2000), while Gatignon and Xuereb (1997) observed similar trend. The possible reason for such a relationship as observed by Lukas and Ferrell premised on the fact that as the quantity of functional units that are involved are increasing, the stress that may be involved may also increase, and the only way to overcome this challenge is to avoid projects that are not familiar and innovative in nature. Another possible reason is that, since internal functional coordination requires that diverse views are merged (Auh \& Menguc, 2005), extremely innovative concepts may lose their 'innovation' as a result of the conciliations which came about in the course of coordination. The author also argued that there is a tendency for internal functional coordination to fail since it also advocates exploitation of pool of talents and can therefore inhibit innovativeness. As a result, the following effects can be predicted:

H3: There is significant effect of internal-functional coordination on firm performance.

H6: There is a significant and positive relationship between internal coordination and product innovation of SMEs in Saudi Arabia.

\section{Product Innovation (PI)}

The accelerating changes in the economic environment, fields of science and technology, globalization and its challenges, changing customer demands, unstable market conditions, and increasing product competition on the market have compelled organizations to enhance their competitive performance (Najafi-Tavani, et al., 2018). This in turn has made innovation for organizations the main pillar of survival under multiple circumstances (Schoemaker, et al., 2018). Because product is the key element, the most important of all marketing mixture elements for organizations for achieving their goals with success and superiority over competitors, it has become mandatory to innovate products in terms of quality, function and constant marketing strategies in order to invade market, gain customer satisfaction and achieve 


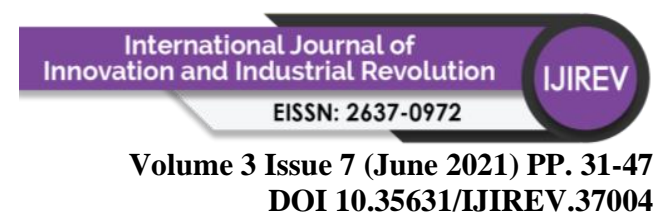

more product demand (Ramadani, et al., 2019; Al-Barry ,2009). The economic and social justification for product innovation depends on the ability to satisfy current and potential consumers' needs and meet the assigned responsibilities (Anwar, et al., 2020). For Bustinza, et al., (2019) and Aqili and Nasser (2010), product innovation means introducing or improving products, processes, or services for the market, and therefore it represents one or all of the following things: A completely new product, improvement of a product on the market, a completely new process and improving an existing process. Shukal et al., (2010) define development as "inventing new ideas and converting them into marketable value in the form of new products or new technologies, as well as improving existing products through modifications". New combinations are being sought to create integration between them and the available potentials for development". Based on the above, (Baron \& Kenny, 1986) illustrate that the mediation happens if the independent variable explains a specific variation in the mediator variable, which in turn interprets a specific variation in the dependent variable. That is, the mediator variable carries the effect of the independent variable into the dependent variable. According to that, Suliyanto and Rahab (2012) recommended the inclusion of innovation to mediate in the relationship between $\mathrm{MO}$ and firm performance. Alongside an increased interest in literature on the relevance and impacts of the market guidance strategy, the debate on its impact on an innovative business and firm performance has been reestablished. There has been debate over whether the majority of market-oriented businesses are less receptive to innovation or simply modify well-known products to meet customer requirements rather than embarking on more radical projects (Prifti, \& Alimehmeti, 2017). As a result, Product innovation is one of the key instruments of growth strategies for entering new markets, increasing existing market share, and providing the company with a competitive edge. Thus, in these instances, as with SME organizations, it is best to assess a source of competitive advantage based on product and process innovation rather than simply on market position (Ali et al., 2017; Slater, 1996). To continue to fulfill their roles in an age of constantly changing technology and markets, they can be flexible, diversified, and inventive (Sahoo \& Yadav, 2017; Vazquez et al., 1998). Previous empirical studies have shown that product innovation is one of the strategic priorities that have a positive and significant impact on the relationship between market orientation and firm performance (Sahoo \& Yadav,2017; Buli, 2017; Sciascia, et al., 2014; Shehu \& Mahmood, 2014; Boso et al., 2013; Kraus, et al., 2012). On the other hand, some authors found that product innovation has a negative effect on the relationship between market orientation and firm performance (Arunachalan, et al., 2013; Andersen, 2010; Naldi, et al., 2007). All these discrepancies in the results of previous studies constitute a research gap that must be studied and confirmed, so this research will examine the mediating effect of product innovation on the relationship between market orientation and firm performance. This discussion leads to the following hypothesis:

H7: There is mediating effect of product innovation between the relationship of consumer orientation and firm performance

H8: There is mediating effect of product innovation between the relationship of competitor orientation and firm performance

H9: There is mediating effect of product innovation between the relationship of internalfunctional coordination and firm performance

H10: There is significant effect of product innovation on firm performance. 


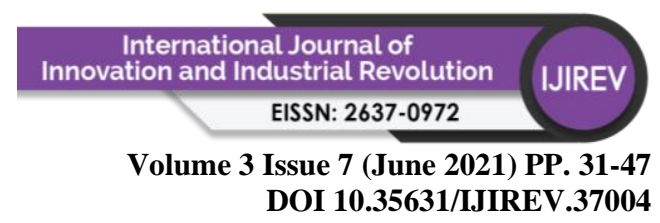

\section{Marketing Ethics (ME)}

In general, ME represents Social and professional practices and standards which the marketing managers are expected to use in order to help them develop, implement and monitor the strategies. (Hollensen, 2003). In addition to that, Abbas, et al., (2019) and Laczniak, \& Murphy, (2006) illustrated that marketing ethics is the principles and standards that define acceptable behaviour in marketing as defined by the general public, government legislators, competitors, and organizations. Specifically, Dunfee et al. (1999) added that marketing ethics is an application field that includes moral principles underlying operation and marketing regulation. It is therefore a process in which companies generate customer interest in products and services, generate stakeholder value and build strong relationships with customers. In today's business world, managers also have to judge what is right or ethical to do in addition to general decisions. It's not a simple task, Johnson (1981) shows that difficulty is generally accompanied by a negative result in the making of ethical choices, sometimes good and bad, as well as a desired result (Ferrell, \& Ferrell, 2021). Furthermore, marketing ethics focuses on how consumer behavior affects ethical issues when buying. Marketing ethics is a place of ethics that deals with the moral principles behind the operation and law of advertising areas such as advertising ethics, product characteristics and environmental ethics, so it plays an important role in the company's boom (Tsalikis, \& Fritzsche. 2013).

Simultaneously, marketing ethics is an important factor that managers can employ to build ethical and moral practices in the organizations, sustain performance, and maintain competitive advantage (Madu, 2012). This is also in line with the arguments of Alhyaly, M. (2019); Adi, \& Adawiyah, (2018); Cameron and Quinn (2011); Sower, \& Sower, (2004); Hunt, S. D., \& Laverie, D. A. (2004) and Hunt, \& Vasquez-Parraga, (1993) Gordon and Ditomaso (1992) who also assert that strong marketing ethics has a powerful effect on the performance of the organization either in the long run or short run. The marketing ethics has been suggested for the performance of the organization (Marri et al., 2013). This is very important because many companies face ethical problems in the present business environment and thus affect their performance and in many cases become a threat to their survival (Manan et al., 2013; Marri et al., 2013). Almost, marketing ethics, as a mediator, can have a suitable mechanism that can explain the relationship between market orientation and organizational performance and resolve the inconclusive findings in the previous literature. In other words, marketing ethics is regarded as the instrument that will provide an explanation for how and why the relationship between market orientation and organizational performance exists (Ferrell, \& Ferrell, 2021). In this regard, the inconsistent results concerning MO-firm performance link combined with the scarcity of studies in SMEs sector indicates the existence of a gap in the literature. Therefore, empirical evidence is necessary to fill this gap. That being the case, this study attempts to investigate the possibility of applying this strategy in SMEs in a scientifically studied manner, and in harmony with its work environment, since most of the top management of these companies have trends towards developing their marketing activities by adopting contemporary strategies in order to serve the market and customers as well. Based on the above discussion, following hypothesis is raised:

H11: ME as a moderator effect positively on the relationship between consumer orientation and firm performance

$\mathrm{H} 21$ : ME as a moderator effect positively on the relationship between competitor orientation and firm performance

H13: $\mathrm{ME}$ as a moderator effect positively on the relationship between internal-functional coordination and firm performance 


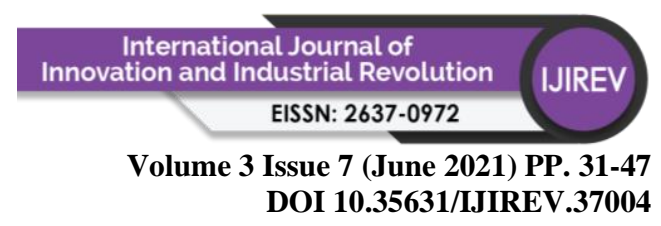

H14: ME effect positively on firm performance.

\section{Firm Performance}

The last two decades have seen an increase in interest among researchers and scholars in the issue of performance measurement and management (Ali, et al.,2017). Because the importance of performance explains how a company performs (Hoque, 2018). According to MadridGuijarro, et al., (2020), the performance measures can give companies accurate information on how performance affects and how companies use and resource planning, build the best strategies, pay attention to consumer preferences, and compete in the most effective manner possible. To create a comprehensive assessment of a business's performance, Venkatraman and Ramanujam (1986) proposed a financial and operational performance model for the business measures. In addition, Gunasekaran, A., \& Kobu, B. (2007); Teeratansirikool, L., Siengthai, S., Badir, Y., \& Charoenngam, C. (2013) Taouab, O., \& Issor, Z. (2019) concluded that five categories of measures can be described as performance; "operational measures (including nonfinancial variables such as market proportions and customer satisfaction); accounting measures (based on financial data); survival measures (long-term organizational performance); marketbased measures (market o value ratios) (adjusted accounting measures)". On the other hand, in assessing firm performance (Kaplan \& Norton, 1992, 1996) introduce the Balanced Scorecard, a strategic model for evaluating the company's performance.

Furthermore, Kaplan and Norton (1992) argued that financial management alone would be inadequate to evaluate the competitive position of an organization. As a result, the balanced scorecard strategy retained financial value while adding three non-financial metrics - client, internal processes, and learning and growth (Kaplan \& Norton, 1992, 1996). Similarly, several studies have suggested that performance evaluations should incorporate both financial and nonfinancial metrics (Ali et al., 2017; Gronum, et al., 2012; Hilman, 2009; Kaplan \& Norton, 2000; MacDougall \& Pike, 2003). The firm performance of this paper is a subsection of corporate efficiency covering financial and non-financial outcomes. On the basis of the above, a theoretical gap has been identified in the literature reviewed that has to be filled as shown by the conceptual model. In particular, the literature has shown that all the structure of the paper has a relationship with the organization's performance. First, MO influences the performance of the company. Some literature report that the variables are positive, while some report that they are negative. As a result of this mixed result, the literature serves as the impetus for this study, which seeks to further explain the relationship between MO and SME performance. Product innovation and marketing ethics have also been introduced to further reinforce these relationships. 


\section{New Conceptual Framework}

Based on the literature review and subsequent hypotheses. To help explain the relationship between the study's variables, the following conceptual model was developed.

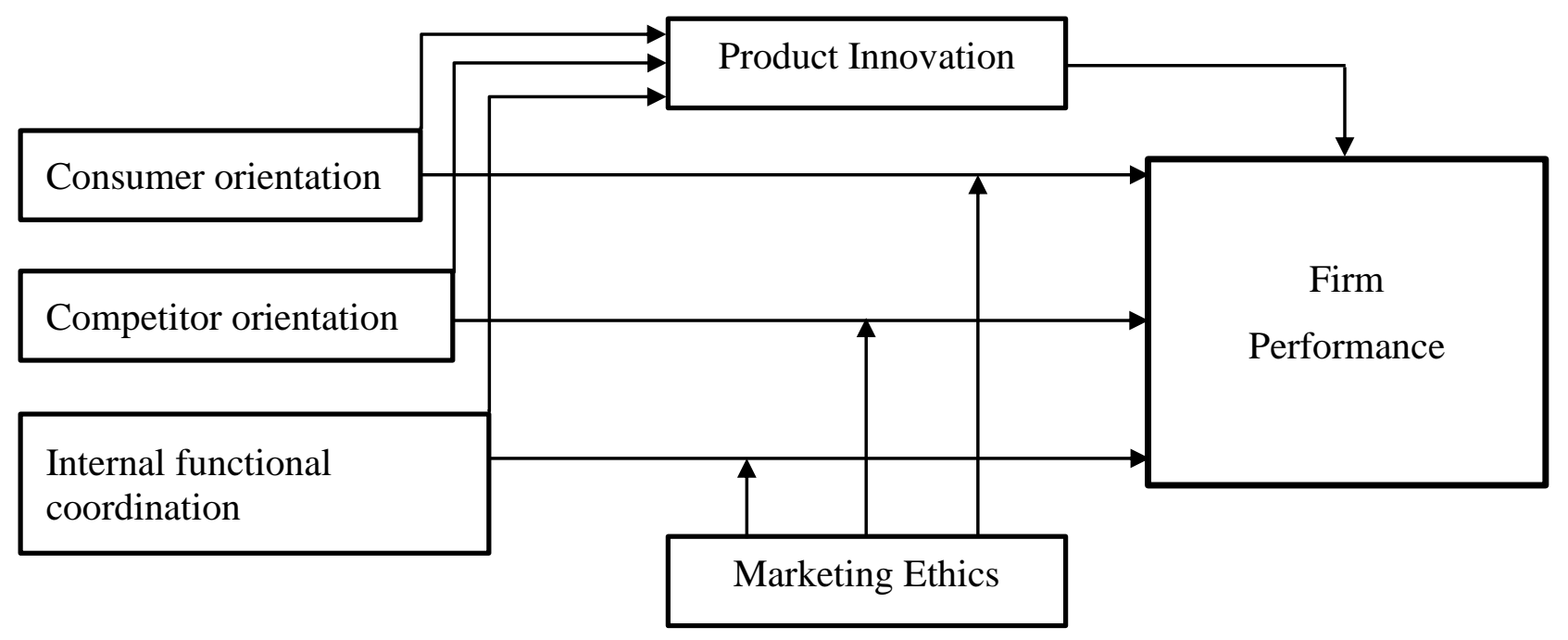

Figure 1: Conceptual Framework

The framework has been created based on the relationships between MO, PI, ME, and SMEs. This correlation is supported through resource-based theory, which ensures on the current internal resources and capability are active in affecting on firm performance. This assumption is built on the principle that an organization can outperform its competition in the market by making better use of its resources. Furthermore, existing research suggests that product innovation can act as a mediator between MO and small and medium-sized enterprises, which contributes to the explanation of the relationship in contrast to the literature's mixed findings. More so, marketing ethics acts as a moderator in the relationship between market orientation and SME performance in order to strengthen the connection between the variables of interest. The framework depicted in Figure 1 is consistent with previous scholars' recommendations (e.g., Ali, et al., 2020; Jabeen et al., 2014; Shehu \& Mahmood, 2014; Raju et al., 2011; Baron \& Kenney, 1986). Product innovation, as a mediating variable, can be used to determine the effectiveness of a business's performance. Furthermore, a positive attitude toward marketing ethics influences the successful implementation of market orientation. A result of this paper is the introduction of a novel research model that will guide SMEs for the first time in making sense in terms of previous research and theories.

\section{Conclusion}

This research paper established a new theoretical framework for connecting MO, PI, ME, and firm performance. Notably, this study makes a significant contribution to the domain of research by establishing a framework for explaining the influence of MO on the Small and medium-sized enterprises. Additionally, this research is rare in that it elucidates the possibility of operating product innovation as a mediator, in addition to the role of marketing ethics as a moderator in the MO -SMEs relationship. One of the study's objectives is to increase managers' 


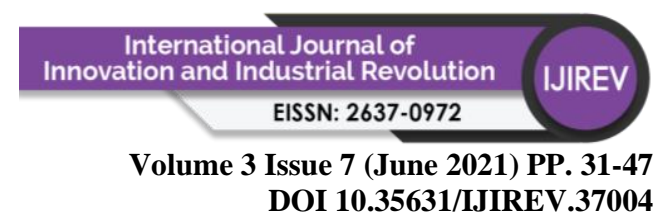

awareness of the importance of MO, PI, and ME in order to help their organizations improve their performance and competitiveness.

\section{Limitation and Future Research}

Nonetheless, this study, like all others, has limitations. To begin, because this is a theoretical paper, upcoming research should empirically prove the study's claim. Second, this model is focused on SMEs; future research should verify its validity in larger companies and different sectors.

\section{References}

Acosta, A. S., Crespo, Á. H., \& Agudo, J. C. (2018). Effect of market orientation, network capability and entrepreneurial orientation on international performance of small and medium enterprises (SMEs). International Business Review, 27(6), 1128-1140.

Adis, A. A. A., \& Jublee, E. (2010). Market orientation and new product performance: The mediating role of product advantage. African journal of marketing management, 2(5), 91-100.

Al-Dhaafri, H. S., Yusoff, R. Z. B., \& Al-Swidi, A. K. (2013). The Effect of Total Quality Management, Enterprise Resource Planning and the Entrepreneurial Orientation on the Organizational Performance: The Mediating Role of the Organizational Excellence--A Proposed Research Framework. International Journal of Business Administration, 4(1), 66.

Alhakimi, W., \& Mahmoud, M. (2020). The impact of market orientation on innovativeness: Evidence from Yemeni SMEs. Asia Pacific Journal of Innovation and Entrepreneurship.

Al-Henzab, J., Tarhini, A., \& Obeidat, B. Y. (2018). The associations among market orientation, technology orientation, entrepreneurial orientation and organizational performance. Benchmarking: An International Journal.

Ali, G. A., Abdullah, H. H., \& Gorondutse, A. H. (2017). The effect of entrepreneurial orientation, market orientation, total quality management and organizational culture on the SMEs performance: A theoretical framework. Journal of Business and Retail Management Research (JBRMR), 12(1), 26-40.

Ali, G. A., Hilman, H., \& Gorondutse, A. H. (2020). Effect of entrepreneurial orientation, market orientation and total quality management on performance. Benchmarking: An International Journal.

Appiah-Adu, K., \& Ranchhod, A. (1998). Market orientation and performance in the biotechnology industry: An exploratory empirical analysis. Technology Analysis \& Strategic Management, 10(2),

Appiah-Adu, K., \& Singh, S. (1998). Customer orientation and performance: a study of SMEs. Management decision.

Arslan, I. K. (2020). The Importance of Creating Customer Loyalty in Achieving Sustainable Competitive Advantage. Eurasian Journal of Business and Management, 8(1), 11-20. DOI:10.15604/ejbm.2020.08.01.002

Augusto, M., \& Coelho, F. (2009). Market orientation and new-to-the-world products: Exploring the moderating effects of innovativeness, competitive strength, and environmental forces. Industrial Marketing Management, 38(1), 94-108.

Aziz, N. A., \& Omar, N. A. (2013). Exploring the effect of internet marketing orientation, learning orientation and market orientation on innovativeness and performance: SME 


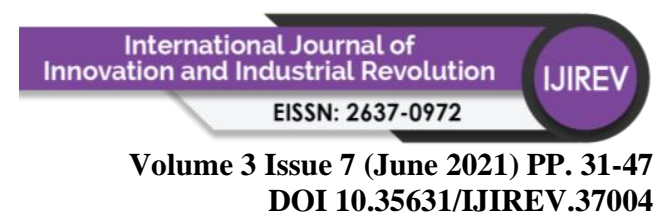

(exporters) perspectives. Journal of Business Economics and Management, 14(sup1), S257-S278.

Aziz, N. A., \& Yassin, N. M. (2010). How will market orientation and external environment influence the performance among SMEs in the agro-food sector in Malaysia? International Business Research, 3(3), 154.

Baron, R. M., \& Kenny, D. A. (1986). The moderator-mediator variable distinction in social psychological research: Conceptual, strategic, and statistical considerations. Journal of personality and social psychology, 51(6), 1173.

Bowden, J. L. H. (2009). The process of customer engagement: A conceptual framework. Journal of marketing theory and practice, 17(1), 63-74.

Calza, E., \& Goedhuys, M. (2017). Entrepreneurial heterogeneity and the design of entrepreneurship policies for economic growth and inclusive development. Routledge handbook of entrepreneurship in developing economies, 529-546.

Carton, RB \& Hofer, CW 2006, Measuring Organizational Performance: Metrics for Entrepreneurship and Strategic Management Research, Edward Elgar, Northampton, MA.

Chao, M. C. H., \& Spillan, J. E. (2010). The journey from market orientation to firm performance: A comparative study of US and Taiwanese SMEs. Management Research Review, 33(5), 472-483.

Chen, Y., Tang, G., Jin, J., Li, J. \& Paillé, P. (2015), "Linking market orientation and environmental performance: the influence of environmental strategy, employee's environmental involvement, and environmental product quality", Journal of Business Ethics, pp. 1-22.

Chiarelli, A. (2021). The impact of dynamic capabilities and market orientation on firm performance: a case study of higher education consulting firms. Small Business International Review, 5(1), e312.

Chin, C. H., Lo, M. C., \& Ramayah, T. (2013). Market orientation and organizational performance: The moderating role of service quality. Sage Open, 3(4), 2158244013512664.

Chin, C. H., Lo, M. C., \& Ramayah, T. (2013). Market Orientation and Organizational Performance. SAGE Open, 3(4), 2158244013512664.

Chironga, M., Leke, A., Lund, S., \& van Wamelen, A. (2011). Cracking the next growth market: Africa. Harvard Business Review, 89(5), 117-+.

Chironga, M., Leke, A., Lund, S., \& van Wamelen, A. (2011). Cracking the next growth market: Africa. Harvard Business Review, 89(5), 117-+.

Day, G. S. (1994). The capabilities of market-driven organizations. Journal of marketing, 58(4), 37-52.

Day, G. S. (1994). The capabilities of market-driven organizations. The Journal of Marketing, 37-52.

De Vos, A., De Hauw, S., \& Willemse, I. (2015). An integrative model for competency development in organizations: The Flemish case. The International Journal of Human $\begin{array}{lll}\text { Resource } \quad \text { 26(20), 2543-2568 } & \end{array}$ https://doi.org/10.1080/09585192.2014.1003078.

Fakhreddin, F., Foroudi, P., \& Ghahroudi, M. R. (2021). The bidirectional complementarity between market orientation and launch proficiency affecting new product performance. Journal of Product \& Brand Management.

Filser, M., Eggers, F., Kraus, S., \& Málovic, É. (2014). The effect of financial resource availability on entrepreneurial orientation, customer orientation and firm performance 


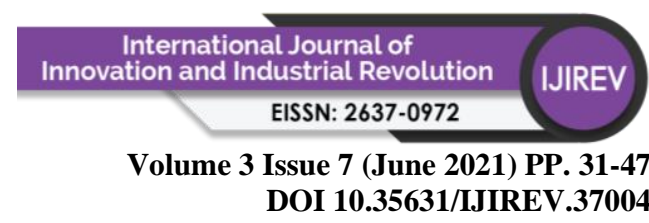

in an international context: an empirical analysis from Austria and Hungary. Journal of East European Management Studies, 19(1), 7-30.

Goedhuys, M., \& Sleuwaegen, L. (2010). High-growth entrepreneurial firms in Africa: a quantile regression approach. Small Business Economics, 34(1), 31-51.

Goksoy, A., Ozsoy, B., \& Vayvay, O. (2012). Business process reengineering: strategic tool for managing organizational change an application in a multinational company. International Journal of Business and Management, 7(2), 89.

Gronum, S., Verreynne, M. L., \& Kastelle, T. (2012). The role of networks in small and medium sized enterprise innovation and firm performance. Journal of Small Business Management, 50(2), 257-282.

Gunasekaran, A., \& Kobu, B. (2007). Performance measures and metrics in logistics and supply chain management: a review of recent literature (1995-2004) for research and applications. International journal of production research, 45(12), 2819-2840.

Hakala, H. (2011). Strategic orientations in management literature: Three approaches to understanding the interaction between market, technology, entrepreneurial and learning orientations. International Journal of Management Reviews, 13(2), 199-217.

Hassim, A. A., Asmat-Nizam, A. T., \& Bakar, A. R. A. (2011). The effects of entrepreneurial orientation on firm organisational innovation and market orientation towards firm business performance. International on Sociality ND Economics Development. IPEDR, $10,280-284$.

Herath, H. A., \& Mahmood, R. (2013). Strategic orientation based research model of SME performance for developing countries. Review of Integrative Business and Economics Research, 2(1), 430.

Herath, H. M. A., \& Mahmood, R. (2013). Strategic orientation based research model of SME performance for developing countries. Review of Integrative Business and Economics Research, 2(1), 430.

Herman, H., Hady, H., \& Arafah, W. (2018). The influence of market orientation and product innovation on the competitive advantage and its implication toward Small and Medium Enterprises (UKM) performance. International Journal of Science and Engineering Invention, 4(08), 08-to.

Hernández-Linares, R., Kellermanns, F. W., \& López-Fernández, M. C. (2021). Dynamic capabilities and SME performance: The moderating effect of market orientation. Journal of Small Business Management, 59(1), 162-195.

Hilman, H. (2009). Relationship of competitive strategy, strategic flexibility and sourcing strategy on organizational performance. Unpublished PhD Dissertation.

Hilman, H., Abubakar, A., \& Kaliapan, N. (2017). The effect of quality culture on university performance. Journal of Business \& Retail Management Research, 11(4), 25-33.

Ho, K. L. P., Nguyen, C. N., Adhikari, R., Miles, M. P., \& Bonney, L. (2018). Exploring market orientation, innovation, and financial performance in agricultural value chains in emerging economies. Journal of Innovation \& Knowledge, 3(3), 154-163.

Ho, S. H., Wu, J. J., \& Chen, Y. (2010). Influence of corporate governance and market orientation on new product preannouncement: evidence from Taiwan's electronics industry. Asia Pacific Management Review, 15(1).

Hopkins, C. D., Ferrell, O. C., Ferrell, L., \& Hopkins, K. H. (2021). Changing Perceptions of Marketing Ethics and Social Responsibility in Principles of Marketing. Journal of Marketing Education, 0273475321995553.

Hoque, A. S. M. M. (2018). Does government support policy moderate the relationship between entrepreneurial orientation and Bangladeshi SME performance? A SEM 


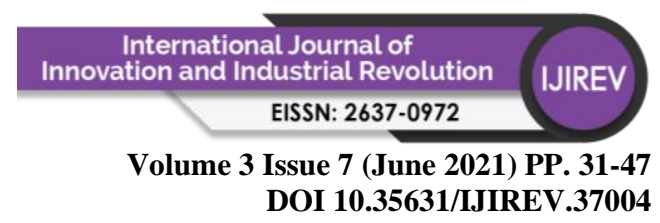

approach. International Journal of Business Economics and Management Studies, 6(3), 37-59.

Hughes, M., \& Morgan, R. E. (2007). Deconstructing the relationship between entrepreneurial orientation and business performance at the embryonic stage of firm growth. Industrial marketing management, 36(5), 651-661.

Islam, M. A., Khan, M. A., Obaidullah, A. Z. M., \& Alam, M. S. (2011). Effect of entrepreneur and firm characteristics on the business success of small and medium enterprises (SMEs) in Bangladesh. International Journal of Business and Management, 6(3), 289.

Islam, M. A., Khan, M. A., Obaidullah, A. Z. M., \& Alam, M. S. (2011). Effect of entrepreneur and firm characteristics on the business success of small and medium enterprises (SMEs) in Bangladesh. International Journal of Business and Management, 6(3), 289.

Jabeen, R. U. B. I. N. A., Shehu, M. S., Mahmood, R. O. S. L. I., \& Kofarmata, B. A. (2014). TQM and Knowledge management impacts on SME performance. International Postgraduate Journal Business Journal,6(2), 23-43.

Jabeen, R., \& Mahmood, R., (2015). The effects of Total Quality Management and Market Orientation on Business Performance of Small and Medium Enterprises in Pakistan. British Journal of Economics, Management \& Trade 5(4): 408-418.

Jiang, W., Rosati, F., Chai, H., \& Feng, T. (2020). Market orientation practices enhancing corporate environmental performance via knowledge creation: Does environmental management system implementation matter? Business Strategy and the Environment, 29(5), 1899-1924.

Joensuu-Salo, S., Sorama, K., Viljamaa, A., \& Varamäki, E. (2018). Firm performance among internationalized SMEs: The interplay of market orientation, marketing capability and digitalization. Administrative sciences, 8(3), 31.

Julian, C. C., Mohamad, O., Ahmed, Z. U., \& Sefnedi, S. (2014). The market orientationperformance relationship: The empirical link in export ventures. Thunderbird International Business Review, 56(1), 97-110.

Kaplan, R. S., \& Norton, D. P. (1996). The balanced scorecard: translating strategy into action. Harvard Business Press.

Kaplan, R. S., \& Norton, D. P. (2000). The strategy focused organisation. Harvard Business School Press, Boston.

Kaplan, R.S., \& Norton, D.P. (1992). The balanced scorecard- measures that drive performance. Harvard Business Review, 70 (1), 71-79.

Keiningham, T., Aksoy, L., Bruce, H. L., Cadet, F., Clennell, N., Hodgkinson, I. R., \& Kearney, T. (2020). Customer experience driven business model innovation. Journal of Business Research, 116, 431-440. https://doi.org/10.1016/j.jbusres.2019.08.003

Keller, K. L., \& Richey, K. (2006). The importance of corporate brand personality traits to a successful 21st century business. Journal of Brand Management, 14(1), 74-81.

Kohli, A. K., \& Jaworski, B. J. (1990). Market orientation: the construct, research propositions, and managerial implications. Journal of marketing, 54(2), 1-18.

Kreuzer, T., Röglinger, M., \& Rupprecht, L. (2020). Customer-centric prioritization of process improvement projects. Decision Support Systems, 133, 113286. https://doi.org/10.1016/j.dss.2020.113286

Lekmat, L., Selvarajah, C., \& Hewege, C. (2018). Relationship between Market Orientation, Entrepreneurial Orientation, and Firm Performance in Thai SMEs: The Mediating Role of Marketing Capabilities. International Journal of Business \& Economics, 17(3).

Li, Y., Liu, X., Wang, L., Li, M., \& Guo, H. (2009). How entrepreneurial orientation moderates the effects of knowledge management on innovation. Systems Research and Behavioral 


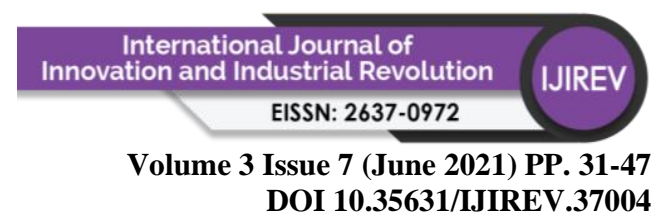

Science: The Official Journal of the International Federation for Systems Research, 26(6), 645-660.

Li, Y., Zhao, Y., Tan, J., \& Liu, Y. (2008). Moderating effects of entrepreneurial orientation on market orientation-performance linkage: Evidence from Chinese small firms. Journal of small business management, 46(1), 113-133.

Madrid-Guijarro, A., Martin, D. P., \& García-Pérez-de-Lema, D. (2020). Capacity of open innovation activities in fostering product and process innovation in manufacturing SMEs. Review of Managerial Science, 1-28.

Moravcikova, D., Krizanova, A., Kliestikova, J., \& Rypakova, M. (2017). Green Marketing as the Source of the Competitive Advantage of the Business. Sustainability, 9(12), 2218.

Morgan, N. A., Clark, B. H., \& Vorhies, D. W. (2019). Market-oriented culture and customer feedback processes. In Handbook on Customer Centricity. Edward Elgar Publishing.

Mostafiz, M. I., Sambasivan, M., \& Goh, S. K. (2021). Antecedents and consequences of market orientation in international B2B market: role of export assistance as a moderator. Journal of Business \& Industrial Marketing.

Mpandare, M., \& Li, G. (2020). Utilising enterprise social media for product innovation: The role of market orientation. Sustainability, 12(9), 3913.

Narver, J. C., \& Slater, S. F. (1990). The effect of a market orientation on business profitability. Journal of marketing, 54(4), 20-35.

Neneh, B. N. (2018). Customer orientation and SME performance: the role of networking ties. African Journal of Economic and Management Studies.

Olabode, O. E., Adeola, O., \& Assadinia, S. (2018). The effect of export market-oriented culture on export performance: Evidence from a Sub-Saharan African economy. International Marketing Review.

Othman, B. A., Harun, A., De Almeida, N. M., \& Sadq, Z. M. (2020). The effects on customer satisfaction and customer loyalty by integrating marketing communication and after sale service into the traditional marketing mix model of Umrah travel services in Malaysia. Journal of islamic marketing. https://doi.org/10.1108/JIMA-09-2019-0198.

Prifti, R., \& Alimehmeti, G. (2017). Market orientation, innovation, and firm performancean analysis of Albanian firms. Journal of Innovation and Entrepreneurship, 6(1), 1-19.

Prifti, R., \& Alimehmeti, G. (2017). Market orientation, innovation, and firm performancean analysis of Albanian firms. Journal of Innovation and Entrepreneurship, 6(1), 1-19.

Raju, P. S., Lonial, S. C., \& Crum, M. D. (2011). Market orientation in the context of SMEs: A conceptual framework. Journal of Business Research, 64(12), 1320-1326.

Salaheldin, S. I. (2009). Critical success factors for TQM implementation and their impact on performance of SMEs. International journal of productivity and performance management.

Schoemaker, P. J., Heaton, S., \& Teece, D. (2018). Innovation, dynamic capabilities, and leadership. California Management Review, 61(1), 15-42.

Singh, S. K., Chen, J., Del Giudice, M., \& El-Kassar, A. N. (2019). Environmental ethics, environmental performance, and competitive advantage: role of environmental training. Technological Forecasting and Social Change, 146, 203-211.

Sisay, D. T., Verhees, F. J., \& Van Trijp, H. C. (2017). The influence of market orientation on firm performance and members' livelihood in Ethiopian seed producer cooperatives. Agrekon, 56(4), 366-382.

Slater, S. F., \& Narver, J. C. (1995). Market orientation and the learning organization. Journal of marketing, 59(3), 63-74. 


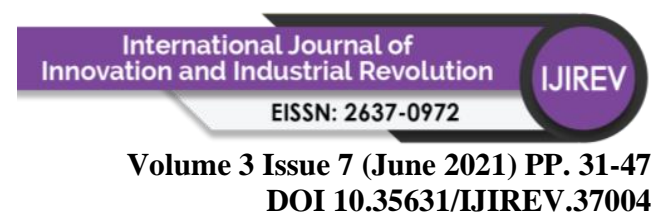

Suliyanto, S., \& Rahab, R. (2012). The role of market orientation and learning orientation in improving innovativeness and performance of small and medium enterprises. Asian Social Science, 8(1), 134.

Taouab, O., \& Issor, Z. (2019). Firm performance: Definition and measurement models. European Scientific Journal, 15(1), 93-106.

Teeratansirikool, L., Siengthai, S., Badir, Y., \& Charoenngam, C. (2013). Competitive strategies and firm performance: the mediating role of performance measurement. International Journal of Productivity and Performance Management.

Udriyah, U., Tham, J., \& Azam, S. (2019). The effects of market orientation and innovation on competitive advantage and business performance of textile SMEs. Management Science Letters, 9(9), 1419-1428.

Wales, W. J., Gupta, V. K., \& Mousa, F. T. (2011). 201 1, Empirical Research on Entrepreneurial Orientation: An Assessment and Suggestions for Future Research. International Small Business Journal, Epub ahead of print, 13.

Wang, C. H. (2019). How organizational green culture influences green performance and competitive advantage. Journal of Manufacturing Technology Management.

Wu, Z., \& Pagell, M. (2011). Balancing priorities: Decision-making in sustainable supply chain management. Journal of operations management, 29(6), 577-590.

Zhang, H., Kang, F., \& Hu, S. Q. (2020). Senior leadership, customer orientation, and service firm performance: the mediator role of process management. Total Quality Management \& Business Excellence, 31(13-14), 1605-1620. 